\title{
Two Aspects of Students' Attitude to Death
}

\author{
Tatiana A. Fen'vesh, \\ Denis V. Lvov and Ekaterina Iu. Zabelina* \\ Siberian Federal University \\ 79 Svobodny, Krasnoyarsk, 660041, Russia
}

Received 03.08.2015, received in revised form 23.08.2015, accepted 11.10.2015

The article analyses the issues of social attitude to death and immortality. Its first part gives a detailed view on the issue of death as a social phenomenon in the cultural and historical context. Its second part provides with the results of sociological study of Siberian Federal University students' opinion. Analysis of the obtained data made it possible to distinguish 2 significantly different aspects of the attitude to death. The authors conclude that the strategy of death avoidance dominates at the level of surface consciousness whereas the strategy of collective ritual caused by existential experiences, on the contrary, dominates on a deeper level. The explanation for this ambivalence of the student mass consciousness undoubtedly requires further research.

Keywords: attitude to death, attitude to immortality, death avoidance, death rituals and traditions.

DOI: 10.17516/1997-1370-2015-8-11-2713-2720.

Research area: sociology.

Death is a natural finiteness of the existence of every living organism, including humans. This essentially biological, descendental understanding of death excludes this phenomenon from social and spiritual and individual human's being, converting finiteness of an individual's existence into infinity of the society's one. However, attitude towards death determines the forms of all religious cults and beliefs. It is the basis for many philosophical principles, scientific research in psychology, anthropology, demography. In this sense, exclusion of the theme of death from the social concept would lead to an irreparable gap in the understanding of a human and his / her existence.
Death as a phenomenon has a certain duality. On the one hand, it is certainly natural, biological and in this sense it is extra-cultural. Presence or absence of culture as a mode of human existence cannot affect the fact of death existence. However, the fact of death existence significantly influences the modes of culture existence and development. Therefore, on the other hand, death is a part of a human's social and cultural dimensions. However, death as a phenomenon of human existence has another exceptional property - a human does not have a lifetime personal experience of death and actually can perceive it only through a universal, supra-individual experience. In this sense it can be argued that perception of death causes some

(C) Siberian Federal University. All rights reserved

* Corresponding author E-mail address: fenvesh@yandex.ru, devlal86@gmail.com,trnzlr@gmail.com 
cultural-historical features of human behavior, the life of modern civilization including (Andreeva, Fen'vesh 2013). In this context death should be regarded first and foremost as an anthropological phenomenon, but not a purely biological cessation of the organism's vital functions.

At the same time the image of death is not static. At different times different societies demonstrate different understanding of death. Much has been written about this within the scope of thanatology (in this regard F. Aries can be called to mind, for example). Thus, it is possible to speak about various social (accepted in a particular society) models of death. Such models are definitely dynamic. Yet they are stable enough in a certain, more or less long period of time to have a noticeable impact on some aspects of social interactions.

The same society can witness coexistence of several models of death at the same time. They may contradict each other, but when it comes to the issues of life-meaningful orientations they may even be in conflict. Sometimes one of the social models of death may prevail over the others for a while, but this does not mean that it will completely replace the alternatives. In this sense it seems reasonable to speak rather about the existence of different types of society's perception of death than about a well drawn up chronology of replacing some models with the others. At this point death as a socio-cultural phenomenon can be regarded in the context of spiritual and practical changes of human existence (Koptseva, Bakhova, Zamaraeva, Kirko 2012; Koptseva, Reznikova 2013). This topic was exhaustively developed in V.G. Nemirovskiy's works in which the images of death were singled out. Ways to overcome the fear of death were also distinguished and classified (Nemirovskiy 2002b). However, it is obvious that different models will be illustrated to a greater extent with the examples from different eras.
For example, it is clear that death and posthumous existence were of a more individualized nature for the ancient people than for the Christians who considered salvation possible only through such a collective institution as the Church. In this context the remark about well-developed names of individual and collective burial places seems interesting:

"It's noteworthy that the ancient Romans had many words naming tombstones (tumulus, sepulcrum, monumentum, and later tumba), but they cared little about naming the place where these tombstones were located. It will not be a great mistake to say that there were no cemeteries but only tombs which were arranged more or less compactly. By contrast, being a public and enclosed space for burials, it was the cemetery that was significant for the medieval mentality. This determines the need to define it as precisely as possible" (Aries 1992, p. 80).

For modern Western society death is more evil than good. In developed countries a substantial excellence of comfort of earthly life leads to the fact that people tend to live an active life till their last breath. The result of invention of ways of treating previously fatal diseases, active struggle for life extension in old age, and rather effective development of gerontological studies is that in the struggle between earthly and otherworldly existence people take the side of the earthly one. This inevitably leads to the fact that a modern Western human considers death to be absolute and inevitable evil. In this context life is a mere resistance to death. This worldview heightens the fear of death, forcing us to search for new ways of overcoming it.

Z. Freud introduced the concepts of "life instinct" and "death instinct" in psychology. Death instinct is an innate and unconscious tendency toward self-destruction and return to the inorganic state. Death instinct (Thanatos) is dialectically opposed to life instinct (Eros); life instinct is 
counterbalanced with death instinct. The fear of death and instinct to it are innate, instinctive forms of human experiences and in this sense life instinct and death instinct are absolutely equal in emotional terms. L. Watson, on the contrary, believes that the fear of death is not an innate but acquired property of psyche. In his opinion, psychological reaction to death is peculiar only to adults. It is the result of their social existence. The value of an individual life as a unique phenomenon grows in accord with humanistic principles of the society development in modern world. However, such an attitude to human life hardly changes the society's attitude to his / her death. There is no doubt that individualization of human life gives rise to many serious problems, the sociological approach being ineffective in resolving them. An individual's mortality is not softened by the society's immortality, as the thesis of infinity of the society's existence is still open. "After us the deluge" life principle is far from being the modern world's invention. The desire to dissolve the fear of death in a game does not shine with originality either. However, it is the modern world that provides a human with more opportunities to live his / her life in accordance with these questionable maxims. For a modern human death is a forbidden subject. It leaves our everyday life, remaining on the periphery of consciousness and losing its moral and meaning-making potential. These are quite alarming symptoms of today and a very serious reason for in-depth sociological, anthropological and philosophical research.

In this context the subject of immortality is also no less exciting for people of any time period. For a human death, no matter how it is understood, has always been the finiteness of life (at least till its stage directly associated with the existence in "this world"). Models of death were developed in order to answer the sacramental question about what is expected later, in "that world". They were sometimes developed so thoroughly that specialized texts containing certain recommendations on how one should behave and what should be said to the other world inhabitants to guarantee the most carefree existence there were written (the Egyptian "Book of the dead", for example). At the same time the pictures of death and further being often frightened those who were alive and naturally tried not only to prevent their own death sufferings as much as possible. The religions of salvation come to the aid. If a person doubts the possibility of salvation from the predicted tortures, he / she naturally begins to strive for the ways to maximally postpone his / her own death (or even cancel it if possible), to stay in "this world" for as long as possible. This opens the space for the emergence of social models of immortality.

It is absolutely natural that each model of immortality will correspond to one or another particular model of death. Such models may be developed not only spontaneously in mass consciousness but also with some social group's participation. Whereas previously these were primarily religious philosophers who theorized on the issues of death and immortality, in the present secularized era quite secular public associations have begun their active play in this field. The idea of developing advanced medical technologies in order to achieve "negligible aging" (that is a state of the organism when all its basic functions no longer depend on the age but remain at the level that are active enough and do not burden with problems) becomes the answer to modern understanding of death as the end of individual existence (including death of consciousness resulting from the cessation of a biological activity of the body) (P. Fedichev). Moreover, some scientists carry out their research in a more radical field of trans-humanism, also embracing serious discussions of the ideas associated with the transfer of human consciousness to a computer carrier, with the subsequent possibility 
of embedding into robotized artificial body. "Russia 2045" movement is probably one of the most vivid examples of such public groups in our country. It unashamedly puts some pathos the following questions:

"Being an intelligent race, we, the humans, must decide for ourselves whether we want to live forever or want to be born and die. Do we want to endlessly develop and learn the secrets of life to riddle the riddles of the Universe, to perfect ourselves life long, including bodily perfection? Do we want the eternal life in an artificial body, or do we want to live in the old manner, the way our ancestors lived hundreds of thousands years ago, that is aging, getting ill and dying?" (A. Ariianov).

Without going deeply into the questions on who the beneficiary of such public platforms is and in what form the beneficiary exists, it might be stated that they are mechanisms designed to influence public consciousness and purposefully making efforts to form specific models of death and practical immortality in mass consciousness. Thus, the possibility of adopting such a model of immortality, in which a human is suggested to replace his / her imperfect and subject to decay body into an "avatar" artificially created and available for repair, raises not so much technological as existential questions. What is a human's nature? Is a human's existence possible beside his / her natural corporality? That is, will the consciousness placed in such an "avatar" still remain a human or will it be a radically different creature? Finally, there arise a number of issues related to nature, structure and organization of a new society with its individuals being the representatives of the "post-humanity"...

Thus, if previous social models of death and immortality to some extent formed not only spiritual but also economic (e.g. associated with the performance of religious rites) life of the society, new models will prospectively have impact on various aspects of social behavior. "Strategic public movement 'Russia 2045" gives a global scale consideration to their projects:

"Avatar" project can be rightly called an epoch-making project for the humanity. Compared to it, the previous megaprojects such as "Manhattan", "Apollo" (the American programme of landing on the Moon), "Star Wars", HAARP, the Large Hadron Collider (LHC), etc., taken together, can seem to be pygmies at the colossus' side" (Ibid.).

This automatically implies concentration of a considerable amount of resources that could be spent on other needs of mankind. We are not inclined to raise the alarm or call to a "witch hunt". It should be just mentioned that, probably, it is not the thing to undertake a serious search for the answers to purely technical questions on finding the same possibility of transferring consciousness into an artificial body without a fundamental solution of such fully philosophical questions as whether the humanity agrees to compromise their own nature by refusal from natural physicality.

In this context the results of sociological research on the Siberian Federal University students' attitude towards death, carried out in 2014 - 2015 at the Sociology Department at SibFU, are of a certain interest. Questionnaire survey was based on a simple probability sample (380 students). It is mass consciousness of today's youth that will determine the strategies which the society will make active use of as time passes.

Among other questions the respondents were asked to rate the degree of their agreement with a number of judgments. The factor analysis showed the relationship of two groups of judgments:

Group 1 includes the following judgments: a) there is nothing after death; b) I dislike a meal after a funeral; c) ceremonies, related to death, only aggravate the grief; d) I am skeptical about funeral repasts. Thus, it reveals that, according 
to the respondents, traditional rituals associated with death affect only those alive. This impact is assessed rather negatively, as it is something that concentrates attention on death instead of serving for consolation and distraction from grief.

Group 2 includes the following judgments: a) I believe in life after death; b) I believe that a person's life determines what will happen after death. Thus, here the belief in after-life is directly associated with the attitude to the influence of life "in this world" on life "in the next world".

In this sense the second group of judgments can be considered as resting on a more traditional and, apparently, religious ideological position than the first group correlating with more secularized consciousness. In other words, the more secular the rituals associated with death are, the less interest and respect they are shown. In addition, one can trace here both the relation between individualization, on the one hand, and the desire to remove the reminders of death, on the other hand. Conversely, attention to death and issues of posthumous being is associated with rituals and, hence, collectivity. Thus, it is possible to hypothesize that two strategies of interaction with the issues of death are implicitly formed in the students' social mind. The first one avoidance of reminders of death - is associated with individualistic attitude and secularism. The second one with its more traditional roots suggests regulating life in accordance with its influence on posthumous existence. This hypothesis undoubtedly requires a more detailed analysis. However, some evidences, proving its right for existence, were obtained in this reconnaissance research.

Thus, avoidance of mentioning death can be observed in the respondents' agreement with the following judgments:

Thus, complete or partial agreement with the fact that they try even not to think about death was expressed by two-thirds of the students. Nearly half of them partially or completely agreed with a negative evaluation of any mentioning death.

At the same time, distribution of answers to the following direct question results in a different picture:

As you can see, two-thirds of the students are against complete avoidance of mentioning death. In addition, more than half of the respondents expressed full or partial agreement with the statements expressing a positive assessment of rituals associated with death that is not in accord with the previously demonstrated avoidance of death:

At that the students are slightly, but still more inclined to believe that it is not worth while medicalizing death. This is evident from their responses to the following statements:

Thus, the respondents do not consider it right to leave a dying man in a special but indifferent environment. Here we can assume that in public consciousness death is a phenomenon which is quite intimate, important, and, probably, in some way uniting family and close ones. This implicitly specifies the importance of death, which cannot be avoided, for the respondents. Whereas the students demonstrate a strategy of avoidance when asked direct questions on mentioning

Table 1. Distribution of answers to the question “How far do you agree with the following judgments?' (\%)

\begin{tabular}{|l|c|c|c|c|c|}
\hline \multicolumn{1}{|c|}{ Judgment } & $\begin{array}{c}\text { I strongly } \\
\text { agree }\end{array}$ & $\begin{array}{c}\text { I rather agree } \\
\text { than disagree }\end{array}$ & $\begin{array}{c}\text { I find } \\
\text { difficulty in } \\
\text { replying }\end{array}$ & $\begin{array}{c}\text { I rather } \\
\text { disagree than } \\
\text { agree }\end{array}$ & $\begin{array}{c}\text { I strongly } \\
\text { disagree }\end{array}$ \\
\hline I try not to think about death & 32 & 34 & 10 & 19 & 5 \\
\hline I dislike any reference to death & 23 & 22 & 15 & 26 & 14 \\
\hline
\end{tabular}




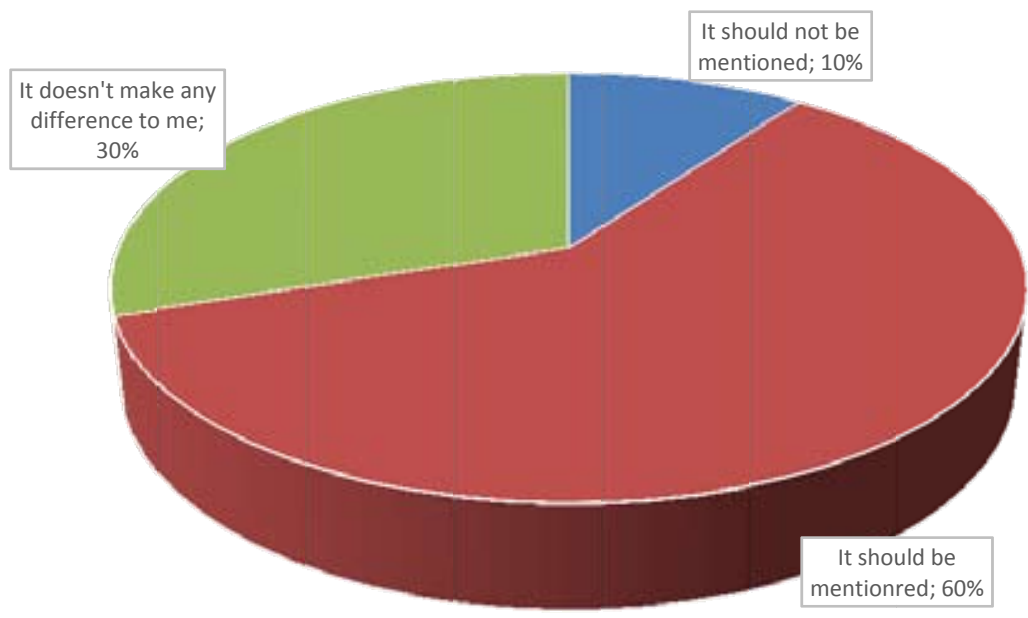

Fig. 1. Distribution of answers to the question "Do you think death should not be mentioned in everyday life" (\%)

Table 2. Distribution of answers to the question "How far do you agree with the following judgments?" (\%)

\begin{tabular}{|l|c|c|c|c|c|}
\hline \multicolumn{1}{|c|}{ Judgment } & $\begin{array}{c}\text { I strongly } \\
\text { agree }\end{array}$ & $\begin{array}{c}\text { I rather } \\
\text { agree than } \\
\text { disagree }\end{array}$ & $\begin{array}{c}\text { I find } \\
\text { difficulty in } \\
\text { replying }\end{array}$ & $\begin{array}{c}\text { I rather } \\
\text { disagree } \\
\text { than agree }\end{array}$ & $\begin{array}{c}\text { I strongly } \\
\text { disagree }\end{array}$ \\
\hline $\begin{array}{l}\text { I believe that death ceremonies } \\
\text { should be regarded positively }\end{array}$ & 57 & 23 & 13 & 5 & 3 \\
\hline Death ceremonies are necessary & 26 & 35 & 21 & 10 & 8 \\
\hline
\end{tabular}

Table 3. Distribution of answers to the question "How far do you agree with the following judgments?" (\%)

\begin{tabular}{|l|c|c|c|c|c|}
\hline \multicolumn{1}{|c|}{ Judgment } & $\begin{array}{c}\text { I strongly } \\
\text { agree }\end{array}$ & $\begin{array}{c}\text { I rather agree } \\
\text { than disagree }\end{array}$ & $\begin{array}{c}\text { I find } \\
\text { difficulty in } \\
\text { replying }\end{array}$ & $\begin{array}{c}\text { I rather } \\
\text { disagree than } \\
\text { agree }\end{array}$ & $\begin{array}{c}\text { I strongly } \\
\text { disagree }\end{array}$ \\
\hline $\begin{array}{l}\text { If a person is death sick, he / she } \\
\text { should be left at hospital }\end{array}$ & 13 & 19 & 28 & 14 & 26 \\
\hline $\begin{array}{l}\text { To my mind, death patient care is } \\
\text { the doctors' duty }\end{array}$ & 17 & 19 & 18 & 22 & 24 \\
\hline
\end{tabular}

death, on the contrary, they demonstrate their greater commitment to the traditional worldview in the matters, directly relating to the situations of facing death. The traditional worldview dictates personal participation in rituals and, therefore, in collective processing of the phenomenon of death. It can be mentioned that the strategy of death avoidance prevails on the level of surface consciousness, whereas, on the contrary, the strategy of a collective ritual, caused by existential experiences, is dominant on a deeper level. These data deepen the results obtained in the course of V.G. Nemirovskiy's research (Nemirovskiy 2002a, 2002b, 2003, 2006, 2011). They laid the basis for an in-depth analysis of death as a sociocultural phenomenon. 
The explanation for this ambivalence of the students' mass consciousness definitely requires more serious consideration. It is not clear, for example, what it should be attributed to: peculiar features of age cohort or fundamental contradiction inherent in our culture as a whole. One thing is sure: the phenomenon of death remains one of the most complex and leaves no one indifferent.

\section{Conclusions}

Generally it can be assumed that this "overcoming and expulsion of death from everyday life" is only one of the strategies used. It coexists with a deep, cautious and in a way respectful attitude to death that still gives the meaning to traditional collective ideas and rituals aimed at the study of the existential phenomenon of death.

\section{References}

Andreev, V.A. \& Fen'vesh, T.A. Smert' kak sotsial'nyi fenomen [Death as a social phenomenon]. Historical, philosophical, political and legal sciences, cultural studies and art history. Theory and practice, 1, part 2. Tambov, Diploma, 2013. Pp. 33-36.

Ar'es, F. Chelovek pered litsom smerti [A man in the face of death]. Moscow, Progress, 1992. $528 \mathrm{p}$.

Ariianov, A. Proekt "Avatar": vse sily chelovechestva - na bor'bu za bessmertie ["Avatar" project: all the forces of humanity for the struggle for immortality!]. Strategic social movement "Russia 2045". Available at: http://www.2045.ru/news/32777.html

Fedichev, P. Prenebrezhimoe starenie [Negligible ageing]. PostNauka. Available at: http:// postnauka.ru/faq/11614

Koptseva, N.P., Bakhova, N.A., Zamaraeva, Iu.P. \& Kirko, V.I. (2012). Problema sotsial'nykh issledovanii sovremennoi gumanitarnoi nauki [The problem of social and cultural studies at contemporary human sciences]. Modern problems of science and education, 3, 323.

Koptseva, N.P., Reznikova, K.V. (2013). Metodologicheskie vozmozhnosti antropologicheskoi shkoly "Kul'tura-i-Lichnost" dlia sovremennykh rossiiskikh sotsial'no-kul'turnykh issledovanii [Methodological possibilities of the anthropological school "Culture and personality" for modern Russian socio-cultural studies]. Modern problems of science and education, 4, 388.

Nemirovsky, V.G. Sovremennaya sotsiololgiia [Modern sociology]. Krasnoyarsk, 2002a. 383 p.

Nemirovskiy, V. G. Bazovye tsennosti $v$ massovom soznanii [Basic values in the mass consciousness]. Krasnoyarsk, 2002b. 78 p.

Nemirovskiy, V.G. \& Starikov, P.A. (2003). Tendentsiia “kvazireligioznosti” v srede krasnoiarskogo studenchestva [The tendency of "quasi-religiosity" among Krasnoyarsk students]. Sociological studies, 10, 96-100.

Nemirovskiy, V.G. \& Sokolova, E.V. Struktura $i$ dinamika smyslozhiznennykh orientatsii studencheskoi molodezhi: postneklassicheskii podkhod [Structure and dynamics of the students' lifemeaningful orientations: post-nonclassical approach]. Krasnoyarsk, 2006. 272 p.

Nemirovskiy, V.G. (2011). Freimy smerti v massovom soznanii sibiriakov: struktura i dinamika (na materialakh sotsiologicheskikh issledovanii v Krasnoiarskom krae i respublike Khakasiia v 2005$2010 \mathrm{gg}$. [Frames of death in mass consciousness of the Siberians: structure and dynamics (based on sociological research in Krasnoyarsky krai and Khakassia Republic in 2005-2010)]. The Monitoring of Public Opinion. Economic and Social Changes Journal, 2 (102), 116-125. 


\section{Два аспекта отношения студентов к смерти}

Т.А. Феньвеш, Д.В. Львов, Е.Ю. Забелина Сибирский федеральный университет Россия, 660041, Красноярск, пр. Свободныій, 79

В статье рассматриваются вопросы социального отношения $\kappa$ смерти и бессмертию. В первой части работы авторами подробно прорабатывается проблема смерти как сочиального феномена в культурно-историческом контексте. Во второй части приведены результаты социологического исследования общественного мнения студентов Сибирского федерального университета. Анализ полученных данных позволил выделить два существенно различных аспекта отношения к смерти. Авторы делают вывод, что на уровне поверхностного сознания превалирует стратегия избегания смерти, в то время как на более глубоком уровне напротив, - стратегия коллективного ритуала, вызванная экзистенциальными переживаниями. Объяснение такой амбивалентности студенческого массового сознания, несомненно, требует дальнеймего изучения.

Ключевые слова: отнотение к смерти, отношение к бессмертию, избегание смерти, ритуаль и традиции, связанные со смертью.

Научная специиальность: 22.00.00 - социологические науки. 